\title{
Use of the geophysical method EM 34-3 in the study of groundwater contamination by coal waste and ashes
}

\author{
Raquel Barros Binotto \\ Elba Calesso Teixeira \\ Antônio Flávio Uberti Costa \\ Arthur Schimidt Nanni
}

\begin{abstract}
The main objective of this paper is to evaluate the efficiency of the geophysical technique EM-34-3 in the study of the groundwater contamination by residues from coal processing. It was applied, in the coal waste and ashes disposal site - $\mathrm{CH} 20$, located in the municipal district of Charqueadas, the electromagnetic geophysical method EM-34-3, which measures the electric conductivity of the medium in subsurface. It was noticed that the highest anomalous electrical conductivity values and ions content were placed inside the disposal site with the most significant contamination situated in the phreatic aquifer. Besides, it was verified an incipient pollution plume in the direction of groundwater flow (to SW). The methodology presented good results in the delimitation of the polluted area, supplying a guiding character for posterior sampling campaigns of contamination groundwater degree and indicating the concentrations of the pollutant elements in subsurface.
\end{abstract}

Key words : groundwater ; geophysical; coal waste; ashes 


\section{RESUMO}

Este trabalho tem por objetivo principal avaliar a eficiência da técnica geofísica EM-34-3 no estudo da contaminação das águas subterrâneas por resíduos do processamento de carvão. Para tanto, foi aplicado, no depósito de rejeitos de carvão e cinzas $\mathrm{CH} 20$, localizado no município de Charqueadas, o método geofísico eletromagnético EM-34-3, que mede a condutividade elétrica do meio, em subsuperfície. Constatou-se que as mais altas anomalias de condutividade elétrica e concentração de íons estavam localizados dentro da área de disposição com a contaminação mais significante situada no aqüífero freático. Além disso, foi verificada uma pluma de poluição incipiente na direção do fluxo da água subterrânea (para SW). A metodologia empregada apresentou bons resultados para a delimitação da área contaminada, mostrando-se de caráter orientativo para posteriores campanhas de amostragens de águas subterrâneas, a partir das quais serão definidos os níveis de contaminação e indicadas as concentrações dos elementos poluentes em subsuperfície.

\section{INTRODUCTION}

The geophysical methods have been always used in the geologic mapping and in prospective campaigns seeking the detection of geophysical anomalies that could indicate, directly or indirectly, the presence of mineral deposits, for instance petroleum and groundwater.

Mainly in the last years, with the growing concern in relation to the environmental problems caused by the improper disposition of solid and liquid residues, geophysical methods have been tested and applied in studies of groundwater contamination - associated to areas of domestic and industrial residues disposal.

In these areas it is sought, starting from the application of the geophysics, to map the extension of the contamination plume, as well as, in certain situations, to monitor its progress in time. With the obtaining of these data, it is possible to guide, with a larger safety, a subsequent campaign of groundwater drilling and sampling, which reduces its physical and financial risks.

With this purpose, electromagnetic inductive methods, as well as those based on electroresistivity and magnetometry, have been applied in the geologic definition of the studied site or in the 
direct identification of the anomalous zones presence, being complemented by either refraction or shallow reflection seismic (ELLERT, et al., 1988).

From the methods above mentioned, electromagnetic inductive method has been the most applied in the investigation of polluted zones, especially due to its rapid execution and reduced necessary team, which allows the densification of the analyzed points number, the improvement in the global resolution of the study and consequently more precise delimitation of the plume contours.

In the Baixo Jacuí Region, mainly in Charqueadas and São Jerônimo cities, a lot of inadequate coal processing residues disposal sites has been reported. In such areas, surface and ground waters presented high contents of suspended solids, acidic $\mathrm{pH}$ values and dissolved metals coming from mine drainage and coal preparation effluents (COPELMI, 1994; BINOTTO et al., 1996; BINOTTO, 1997). Besides, many of inadequate coal waste and ashes disposal sites are inside the urban perimeter of cities, which directly affechs the population of the deposits neighborhood.

In this context, the results obtained from the application of the geophysical technique EM-34-3 in a coal waste and ashes disposal site $(\mathrm{CH} \mathrm{20})$ are here presented, seeking the detection of the groundwater contamination plume.

The choice of $\mathrm{CH} 20$ disposal site for the application of the geophysical method is justified by the factors below:

(i) the precise delimitation of the areas occupied by coal waste and ashes in field, making easy the definition of blank and potentially polluted points;

(ii) significant size of the area occupied by the deposit, which is considered the largest deposit in the entire region - $30 \mathrm{ha}$;

(iii) disposal of residues directly on a flooded area (swamp), with shallow water table (close to the surface), which configures a quite delicate situation in terms of groundwater contamination;

(iv) location of this deposit close to an area with native forest - Capão da Roça;

(v) absence of anthropic occupation (except for some portions at Northeast and Southwest of the area), which facilitates the procedure of geophysical data acquisition with the reduction of interference noises (constructions, fences, electric nets...);

(vi) access to the detailed map of the area occupied by the deposit 
in the scale 1:1000 (TEIXEIRA et al., 1996);

(vii) the proprietor interest in the developed studies seeking the recovery of this area, in which the presence of protection channels is observed around the deposit (eastern and western limits), as well as attempts to revegetation.

\section{STUDY AREA}

The studied area comprises the coal waste and ash disposal site CH 20 - Capão da Roça, located in Charqueadas city, in the Baixo Jacuí Region, approximately $60 \mathrm{~km}$ away from Porto Alegre, Rio Grande do Sul State capital (Figure 1).

The deposit $\mathrm{CH} 20$, a property of the COPELMI Company, constitutes the largest area used as waste deposit in Charqueadas city. A lake occupies the northern limit of the deposit, as well as native forests and capons covered by eucalyptuses associated to sparse native bushes. To the south and to west the same sequence of nuclei covered by eucalyptus occurs and to east a wire fence separates a strip of low native grass.

This deposit is located in an area topographically plane with phreatic level very close to the surface - a swamp area. It's laid on clay-conglomerate-sand fluvial sediments and clayish soil of organic character. The sense of groundwaters flow is preferentially sideways, to Southwest.

On the coal waste layer deposited and compacted (coming from the Charqueadas ${ }^{1}$ preparation plant), there was not a covering of the exposed surface. Some fruitless attempts of revegetation were accomplished in the SE portion of the deposit. Only the areas of ash disposal located in the north and northeast portions of the deposit were revegetated with eucalyptuses (northern portion) and with native vegetation (grass-like, bushes).

In the eastern and western limits protection channels were intercepted, which capture the flowing waters in direction of the southern face, where they reach the natural drainage of the area. In the eastern and southern limits of the deposit significant damages are observed to the vegetable covering, where the strip of located native vegetation between the disposal slope and the protection channel was totally destroyed.

${ }^{1}$ Coal exploration began in 1956, in an underground mine, in Charqueadas County, in the same year the construction of Charqueadas Power Station - TERMOCHAR began. The station commenced its commercial operation in 1962. All the coal explored particularly in this mine and in another located in the proximity was conducted to the Charqueadas preparation plant, which was in operation until late 80 's. 
It's important to stand out the presence of a nucleus of native vegetation denominated Capão da Roça in the northern limit of the deposit - close to the lake, and that is considered by Municipal Legislation, a preservation area.

In recent papers (BINOTTO, et al., 1996, 1999; BINOTTO, 1997), studies of characterization of residues disposed in this area were accomplished and variations in the physical, chemical and physical-chemical characteristics were verified, depending on the residue type (coal waste or ashes) and/or on the sampling depth.

The samples of coal waste taken at deeper levels $(2.00$ to $8.00 \mathrm{~m}$ ), with coarser particle size range, presented more acidic $\mathrm{pH}$ values and higher contents of total sulfur, indicating the presence of sulfides, mainly pyrite, whose oxidation, probably, is still happening. In the samples collected in shallower levels (up to 2.00 $\mathrm{m})$, which present fine-to-medium particle size range, $\mathrm{pH}$ values wereclose to the neutral range. This can be explained by the fact that the oxidation of the sulfides is likely to have been concluded, due to facilitated action of weathering processes on the surface of these deposits. The ash samples presented, as it should be expected, neutral to basic $\mathrm{pH}$ values and low contents of sulfur.

In relation to the pollutant potential of the studied residues, tests of total extraction and lixiviation were done (BINOTTO, et al., 1996, 1999; BINOTTO, 1997), and high concentrations of total $\mathrm{Fe}, \mathrm{Pb}$ and $\mathrm{Zn}$ were found in coal waste as well as a significant lixiviation index of the elements $\mathrm{Mn}, \mathrm{Zn}$ and $\mathrm{Ni}$.

\section{EXPERIMENTAL}

Starting from the definition of the area-objective, the first step for the application of the method EM-34-3 was the placement of pickets according to a regular mesh of $80 \times 80 \mathrm{~m}$, for posterior conductivity reading in the points previously marked. In the Figure 2 the location of the geophysical stations is observed (321 stations in the total) disposed according to a system of relative coordinates tied to a zero initial point randomly chosen. In this way, the coordinates of each point represent the real ground distance of each point in relation to the base line defined starting from the establishment of the initial point 0/0 (Figure 2).

The electromagnetic EM-34-3 method was applied, on this mesh of points previously defined, as described below. The conductivimeter EM-34-3 (MCNEILL, 1980) used is composed by 
two coils, one receiver and one transmitter, and three cables of reference of different lengths $(10,20$ and $40 \mathrm{~m})$. The transmitting coil emits a primary field $\mathrm{Hp}$, which induces electric current in subsurface, generating a secondary electric field $\mathrm{Hs}$. The receiving coil measuresthe combination of these two fields. Under certain conditions, which are technically defined as "low induction operations", it is admitted that the relationship among the modules of the two fields may be expressed as $\mathrm{Hs}=\mathrm{k} \times \mathrm{Hp}$, in which the value of $\mathrm{k}$ depends on the field frequency, on the magnetic vacuum permeability, on the spacing among the coils and on the electric conductivity of the medium (COSTA \& FERLIN, 1994).

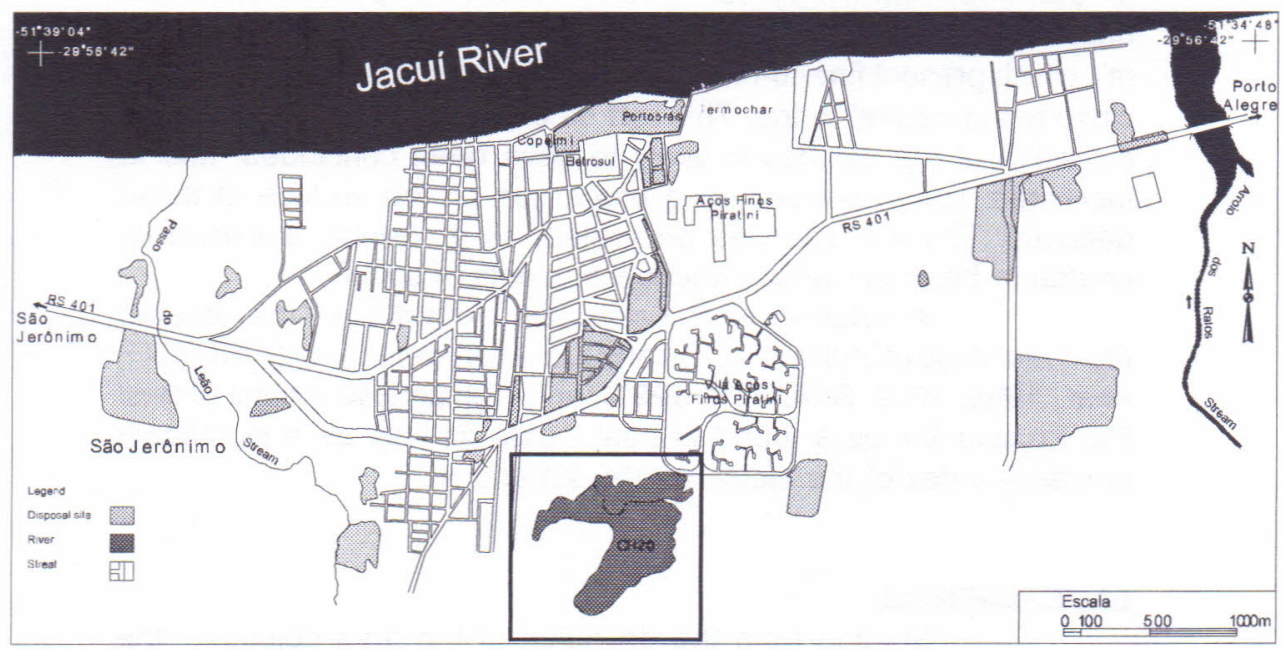

Figure 1: Location of the studied area.

In the practice, the equipment allows the direct measurement of the electric conductivity and the Figure 3 dedemonstrates, schematically, its application.

The depth of the investigation depends on the distance among the coils and on the used arrangement: vertical or horizontal dipole (position-plan of the coils). The obtained information is significant for the spacing conditions among coils specified in the Table 1.

40 Ciência \& Natura, Santa Maria, 23: 35 - 58, 2001. 


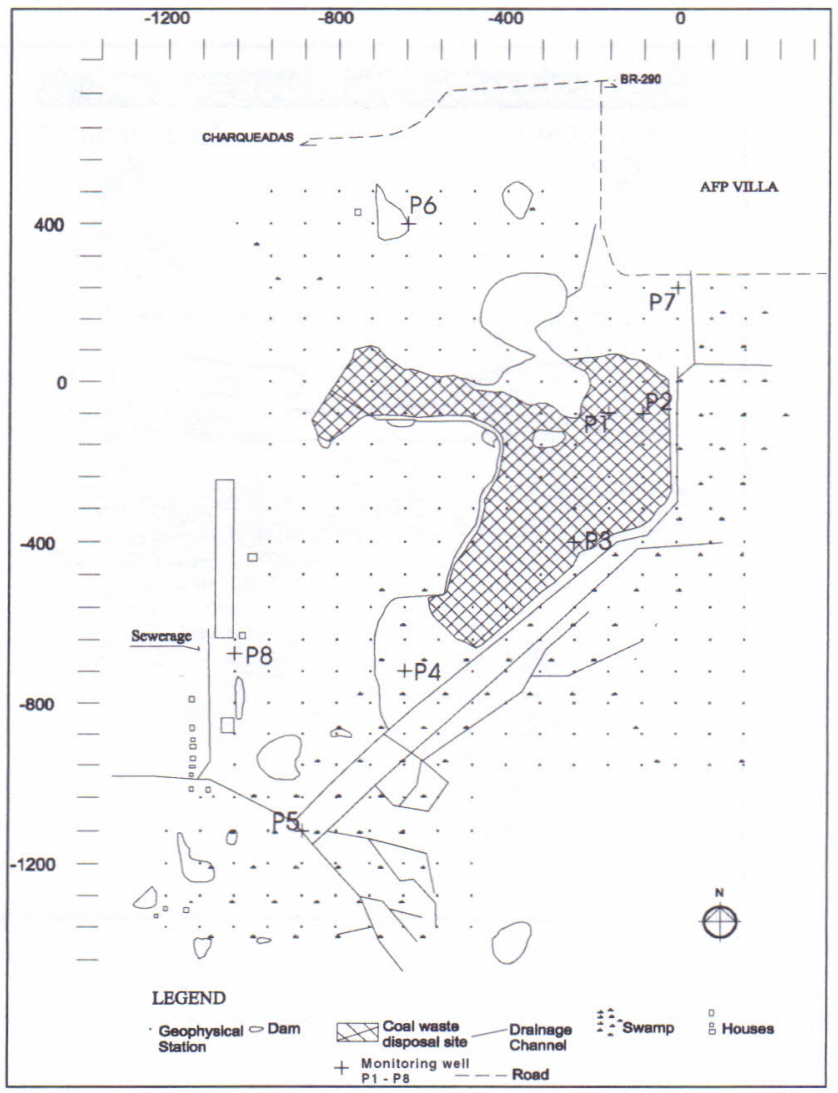

Figure 2: Location of geophysical stations at nr. 30 disposal site, in

In the studied area, the arrangement vertical dipole was used on depths of $7.5 \mathrm{~m}-15 \mathrm{~m}-30 \mathrm{~m}$. In a next office step, the obtained conductivity data were appropriately treated and interpreted. In this study the following software were used for generation of the geophysical maps and/or in the statistical treatment of the geophysical data: SURFER 5.0 FOR WINDOWS, GEO-EAS (public domain Geostatistical Environmental Assessment Software, distributed by the Environmental Protection Agency - EPA/USA), VARIOWINä and STATISTIC 4.3 FOR WINDOW ${ }^{\text {TM }}$. 


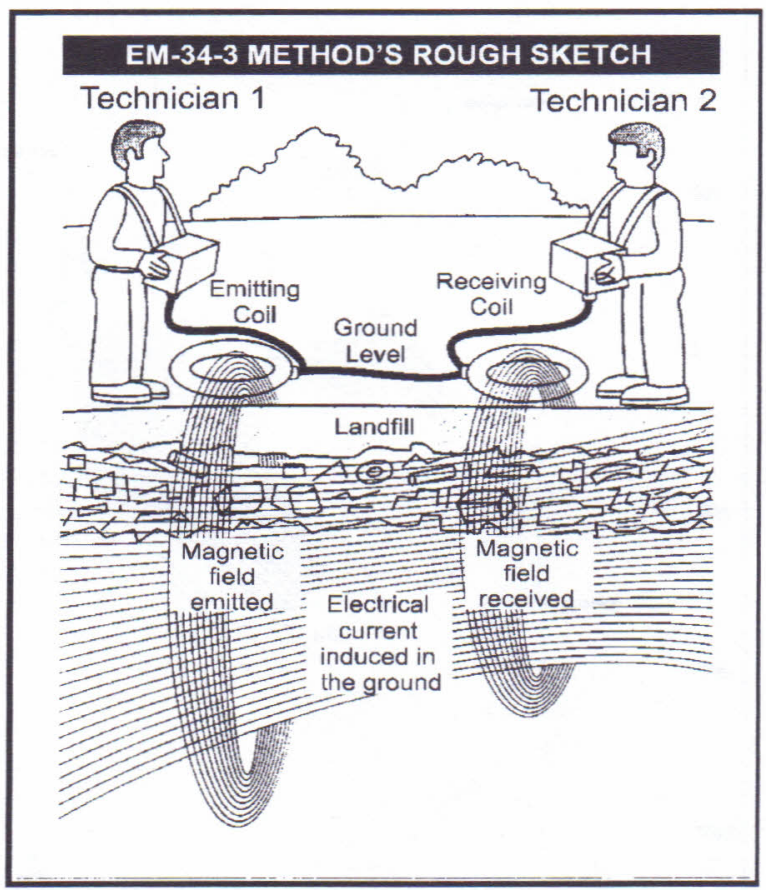

Figure 3: Explanatory outline of the method EM-34-3 (COSTA \& FERLIN, 1994)

After the application of the geophysics in the $\mathrm{CH} 20$ coal waste and ashes deposit, it was proceeded also to a tachometric measurement that consisted of obtaining the quota of each of the geophysical stations in that the conductivity measurement were accomplished. The obtained data were negotiated and compared with the obtained results of the geophysics, in order to observe the influence of the topography of the land on the geophysical data.

Besides the complementary tachometric measurement, studies of groundwater sampling were developed, as previously reported (COPELMI, 1994). The groundwater sampling was conducted monthly, from April/96 to April/97, on seven groundwater monitoring 
Table 1: Position, spacing of the coils and reached depth.

\begin{tabular}{ccc}
\hline Position of the Coils & Spacing among Coils & Reached depth \\
\hline Vertical & $10 \mathrm{~m}$ & $7.5 \mathrm{~m}$ \\
Vert1ical & $20 \mathrm{~m}$ & $15 \mathrm{~m}$ \\
Vertical & $40 \mathrm{~m}$ & $30 \mathrm{~m}$ \\
Horizontal & $10 \mathrm{~m}$ & $15 \mathrm{~m}$ \\
Horizontal & $20 \mathrm{~m}$ & $30 \mathrm{~m}$ \\
Horizontal & $40 \mathrm{~m}$ & $60 \mathrm{~m}$ \\
\hline
\end{tabular}

wells, according to the norm ISO 5667-11 (1990). The samples destined to metals determination were preserved in $\mathrm{pH}<2$ with $\mathrm{HNO}_{3}$. The samples destined to ferrous ion were preserved with $2 \mathrm{ml} \mathrm{HCL}$ conc. / $100 \mathrm{ml}$ (NBR 9898/1987). Determination of metal concentration in groundwater were performed with the aid of a Jobin-Yvon sequential inductively coupled plasma spectrometer, model ICP-38S, coupled to an ultrasound nebulizer to low concentrations and physicalchemical parameters, including ferrous ion, were determined followed procedures recommended by the APHA (1992). The following parameters were determined: Eh, conductivity, total dissolved solids (TDS), $\mathrm{pH}$, dry residue, sulfates, ferrous iron, alkalinity, $\mathrm{Cd}, \mathrm{Co}, \mathrm{Cu}$, $\mathrm{Pb}, \mathrm{Ni}, \mathrm{Mn}, \mathrm{Cr}, \mathrm{Fe}, \mathrm{Zn}, \mathrm{Al}, \mathrm{Ca}, \mathrm{Mg}, \mathrm{Na}$ and $\mathrm{K}$. The obtained results were statistically manipulated using the Factor Analysis Method contained in the STATISTIC 4.3 FOR WINDOWS software, which synthesizes all information in a General Groundwater Index (G.G.I.).

\section{RESULTS AND DISCUSSIONS Validation of the sampling mesh}

The Figure 2, previously presented, illustrates the location of the measurements, usually spaced $80 \mathrm{~m}$ away from each other, in profiles also at each $80 \mathrm{~m}$. Each station can be located by its coordinates $X$ (direction $E-W$ ) and $Y$ (direction $N-S$ ), in relation to the zero point, as referred in the text.

After the collection of data, omnidirectional semivariograms were executed for the measured three levels of electric conductivity (Figures 4, 5 and 6). In all cases, semi-variograms were 
similar in shape when adjusted to the spherical model, with reach around $400 \mathrm{~m}$, what demonstrates that the spacing employed in this study, $80 \mathrm{~m}$, was more than sufficient for the conductivity assessment of the method in the three levels of depth. However, it must be observed that the range is still larger, around $600 \mathrm{~m}$, for the shallowest level (up to $7.5 \mathrm{~m}$ ) when the directional semi-variogram is rotated in the direction of flow of the groundwaters (for SW: 225 degrees), as shown in Figure 7.

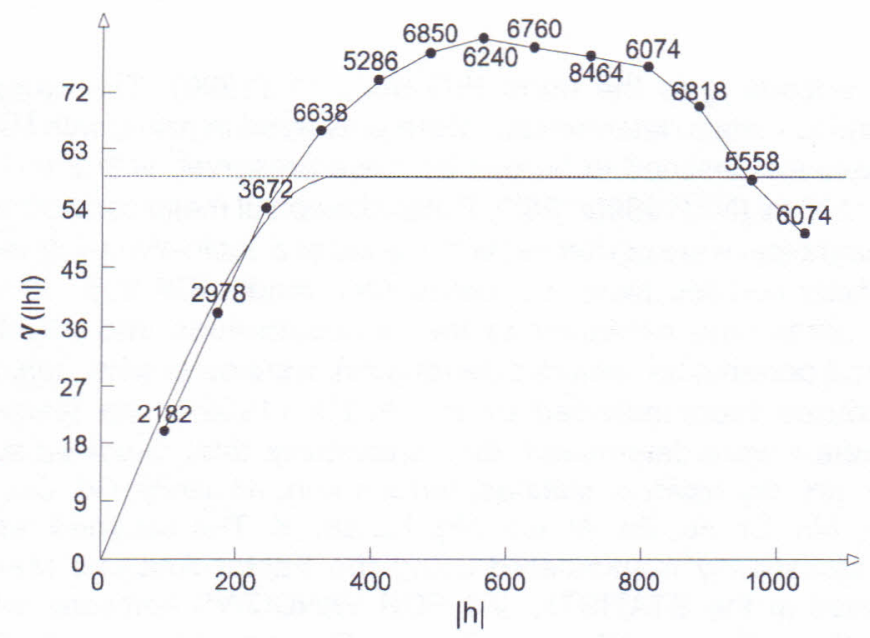

Figure 4: Omnidirectional semi -variogram generated for values of electric conductivity (mS) - level 7.5 m. Gamma (h): 59 * Sph 341(h).

\section{Geophysics}

\section{Level $7.5 \mathrm{~m}$}

The application of the method EM-34-3 in the study area allowed to obtain electric conductivity values for the shallowest level i.e., up to $7.5 \mathrm{~m}$. The simple visualization of data (Figure 8), above all in the in threedimension representation, allowed verifying that the highest values coincide with the area of the deposit. The measured values lie between 0.0 and $34.50 \mathrm{mS} / \mathrm{m}$, with mean equal to 8.86 and standard deviation equal to $7.68 \mathrm{mS} / \mathrm{m}$. 


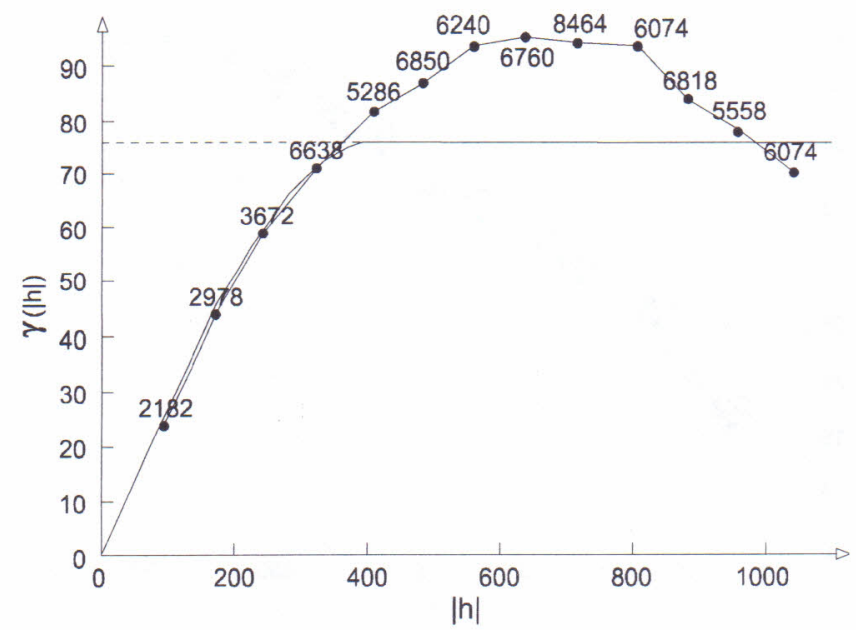

Figure 5: Omnidirectional semi -variogram generated for values of electric conductivity (mS) - level 15 m. Gamma (h): 76 * Sph 407 (h).

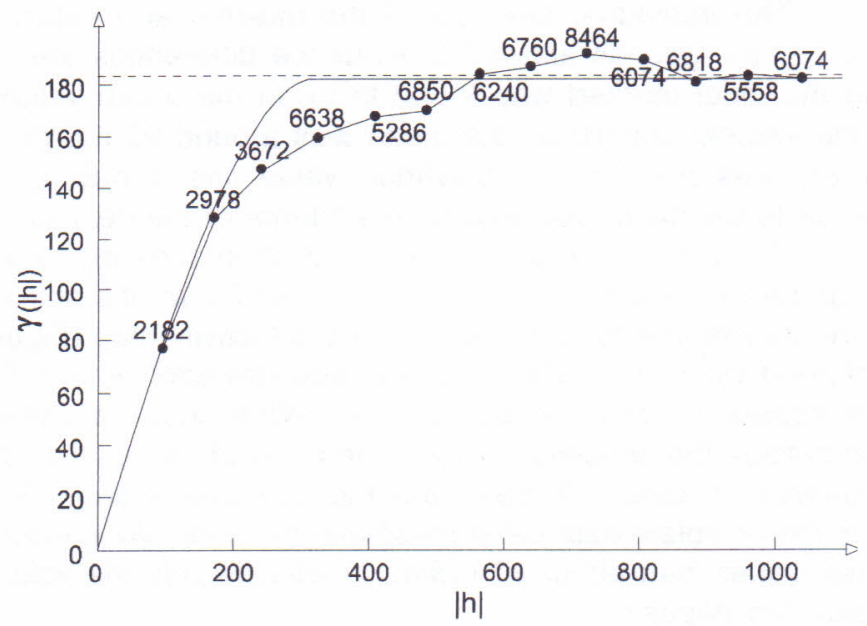

Figure 6: Omnidirectional semi -variogram generated for values of electric conductivity (mS) - level 30 m. Gamma (h): 182.4 * Sph 319 (h). 


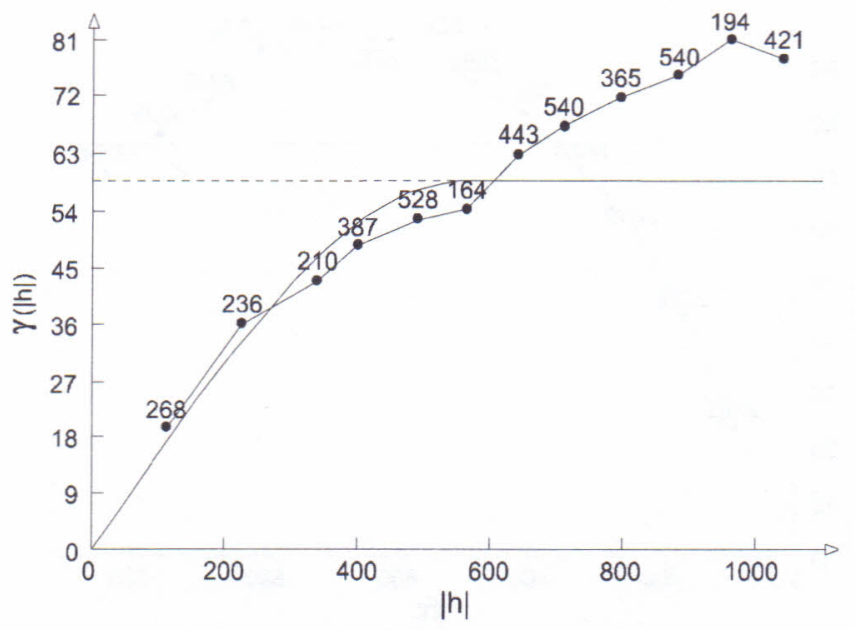

Figure 7: Omnidirectional semi -variogram generated for values of electric conductivity (mS) - level 7.5 m. Gamma (h): 59 * Sph 561(h)

The individual analysis of the internal and external populations to the deposit allowed to evidence differences among them and the most marked was found to be in the mean values: while in the internal population the mean was around $23 \mathrm{mS} / \mathrm{m}$, in the external it was only $6 \mathrm{mS} / \mathrm{m}$. Maximum value was $30 \mathrm{mS} / \mathrm{m}$, not very superior to the mean obtained for the interior of the deposit.

From the viewpoint of detected anomalies indicating probable groundwater contamination in the level $7.5 \mathrm{~m}$, it's noticed that the anomaly tendency observed in the conductivity map (Figure 8 ) is confirmed when the values 1.5 standard deviation above the mean are separated from the background. When just the values measured outside the deposits are examined, it is observed that the values superior to about $13 \mathrm{mS} / \mathrm{m}$ are the anomalous ones. The analysis of the complete data set showed that the anomalous values were those higher than about $20 \mathrm{mS} / \mathrm{m}$, practically only the values taken inside the deposit.

The Figure 8 synthesizes the results obtained for the level up to $7.5 \mathrm{~m}$, presenting the contours of the conductivity variation and the location of the detected anomalous (superior to $13 \mathrm{mS} / \mathrm{m}$ ) values. 

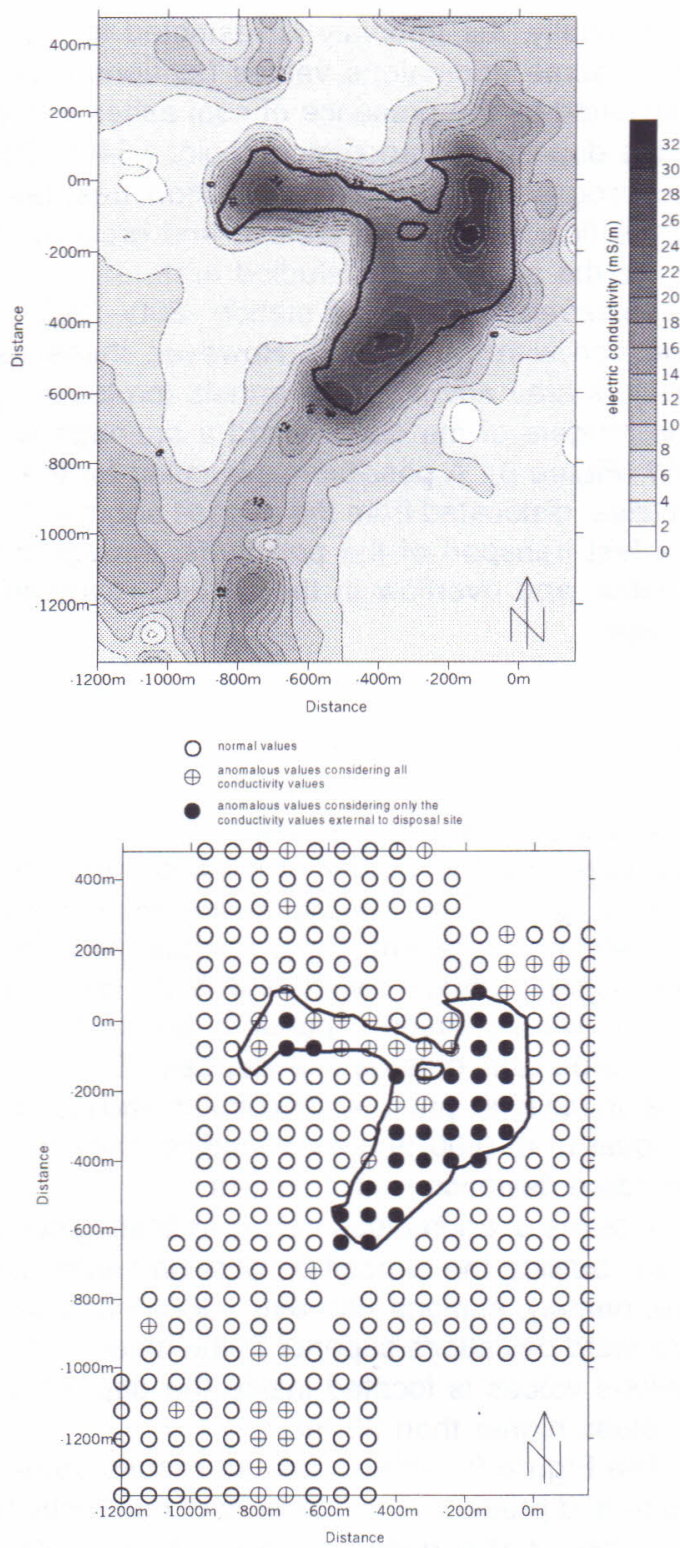

Figure 8:.Map of electric conductivity variation and location of detected conductivity anomalous values in the $7.5 \mathrm{~m}$ level 
Basically, the anomaly is restricted to the deposit. In the NE portion, some anomalous values (stations $0 / 160$ and -80 / 240) were explained by the presence of coal ashes in the place. To the south of the deposit, the anomalous point $(-640 /-720)$ indicates the probable progress of the contamination besides its limits, according to the flow direction of surface and groundwaters in the site (to SW). To the south of the studied area, several anomalous values were observed (around the station -800/-1200), seemingly without connection with the deposit. However, these values were located in the fork area among the channels (protection pipes) that lie around the borders of the deposit and a drainage with traverse direction - NW (Figure 8). A possible explanation for the occurrence of such anomalies, dislocated from the deposit about $400 \mathrm{~m}$, it would be to admit a fast transport of the pollutants, through the channel, with accumulation and overflow in the barrier, represented by the traverse drainage.

\section{Level $15 \mathrm{~m}$}

The application of the method EM-34-3 in the area in study allowed obtaining the values of electric conductivity for the intermediary level, up to $15 \mathrm{~m}$. The visual analysis (Figure 9), mainly of the threedimension representations, reveals, as in the previous case, that the highest values coincide with the deposit contours. The difference, however, doesn't appear to be so clear among the values taken inside and outside the deposit. The accomplished measurements, in the total, presented minimum and maximum values respectively equal to of 0.00 and $43.50 \mathrm{mS} / \mathrm{m}$, with mean equal to 19.56 and standard deviation of $8.67 \mathrm{mS} / \mathrm{m}$.

In terms of anomalous values indicating contamination, just three points outside the deposit borders had surpassed $34 \mathrm{mS} /$ $\mathrm{m}$. They were, namely, stations $-80 /-640,-560 /-640$ and $-1120 /-960$ (above 1.5 standard deviations superior to the mean). The remaining of the anomalous values is located inside the deposit and present conductivity values higher than $32 \mathrm{mS} / \mathrm{m}$.

The Figure 9 synthesizes the results obtained for the level up to $15 \mathrm{~m}$ and presents the contours of conductivity variation and the location of the detected anomalous values. Such anomalous values concentrate inside the deposit, in its NE part, are indicating a larger vulnerability to the contamination, in depth, 

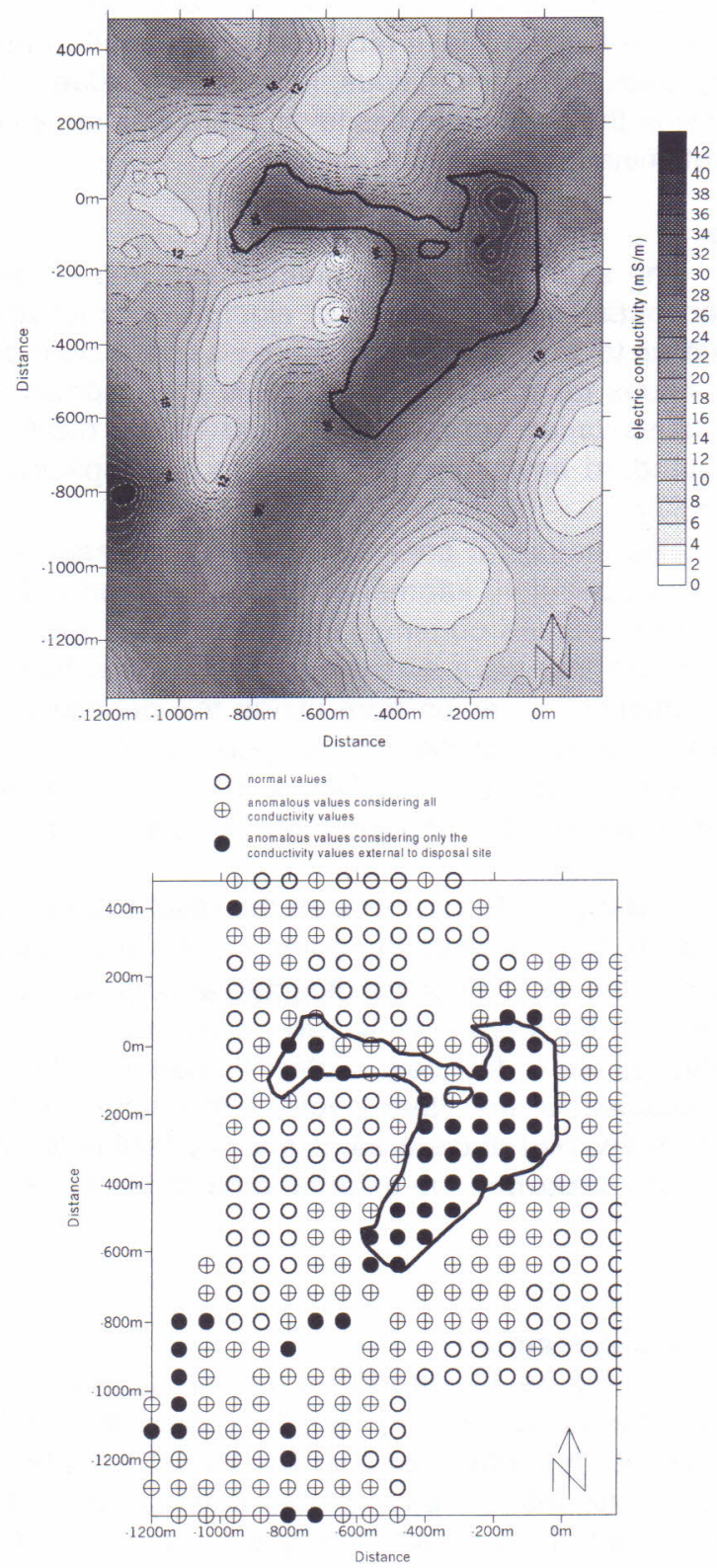

Figure 9. Map of electric conductivity variation and location of detected anomalous conductivity values in the $15 \mathrm{~m}$ level 
what can be explained by the presence of a sandier, permeable stratum, that facilitates the infiltration of the pollutants to the intermediary level. Other anomalous, less intense values, appeared dispersed inside the deposit. In this level, there was not evidence of external contamination due to the deposit.

\section{Level $30 \mathrm{~m}$}

The application of the method EM-34-3 in the studied area allowed obtaining the values of electric conductivity for the deepest level, up to $30 \mathrm{~m}$. Apparently, there was not a clear distinction among the values taken inside and outside the disposal site. The measured values varied between 20.60 and $105.00 \mathrm{mS} / \mathrm{m}$, and the mean and standard deviation were found to be respectively 45.98 and $12.44 \mathrm{mS} / \mathrm{m}$.

The statistical analysis of the 296 measurements in this deeper level, being 46 internal at the deposit and 247 external, revealed that the values obtained for the external group weren't dissimilar to those that have all the information. This fact indicates that the introduction of values from inside the deposit didn't alter significantly the behavior of the external population.

In terms of anomalies (Figure 10), they were those higher than approximately $64 \mathrm{mS} / \mathrm{m}$, for the three groups (internal, external and total).

The Figure 10 synthesizes the results obtained for the level up to $30 \mathrm{~m}$ and presents the contours of the variation of the conductivity and the location of the detected anomalous values, i.e., those higher than $64 \mathrm{mS} / \mathrm{m}$. Only two anomalous values located inside the deposit were detected, in the NE portion, which confirm the results obtained for the other levels, with a larger infiltration of the pollutants in this part of the area. It wasn't possible to detect any plume due to the deposit in the external area to the same.

\section{Tachometric assessment}

The Figure 11 introduces the topographical model of the area of the deposit $\mathrm{CH} 20$, in which the tachometric assessment was accomplished. It is observed that the lowest altitudes coincide with the deposit and with the swamp area that surrounds the same, in the southern part of the area. The highest portions are located in the north part of the area, coinciding with the area of native vegetation - Capão da Roça. 


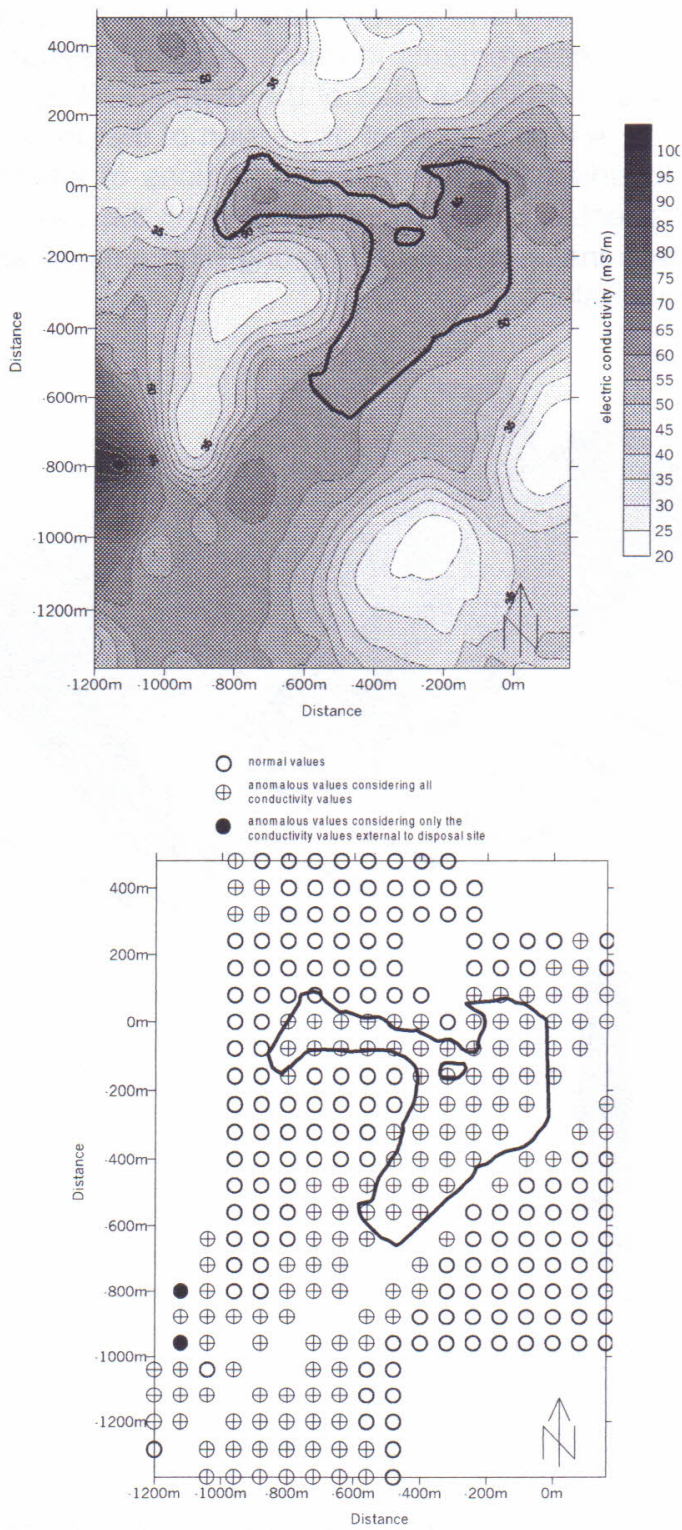

Figure 10: Map of electric conductivity variation and location of detected conductivity anomalous values in the level of $30 \mathrm{~m}$ 
The Figures 12 to 14 correspond to the existent correlation among the topography (Figure 11) and the electric conductivity measurements in depth, respectively for the levels 7.5 $\mathrm{m}, 15 \mathrm{~m}$ and $30 \mathrm{~m}$ in the area of the deposit $\mathrm{CH} 20$.

A high degree of dispersion of the points was identified and it's observed that the measured values of electric conductivity were not affected by the topography, in all the three levels studied and no relationship was found among high altitude and low electric conductivity values.

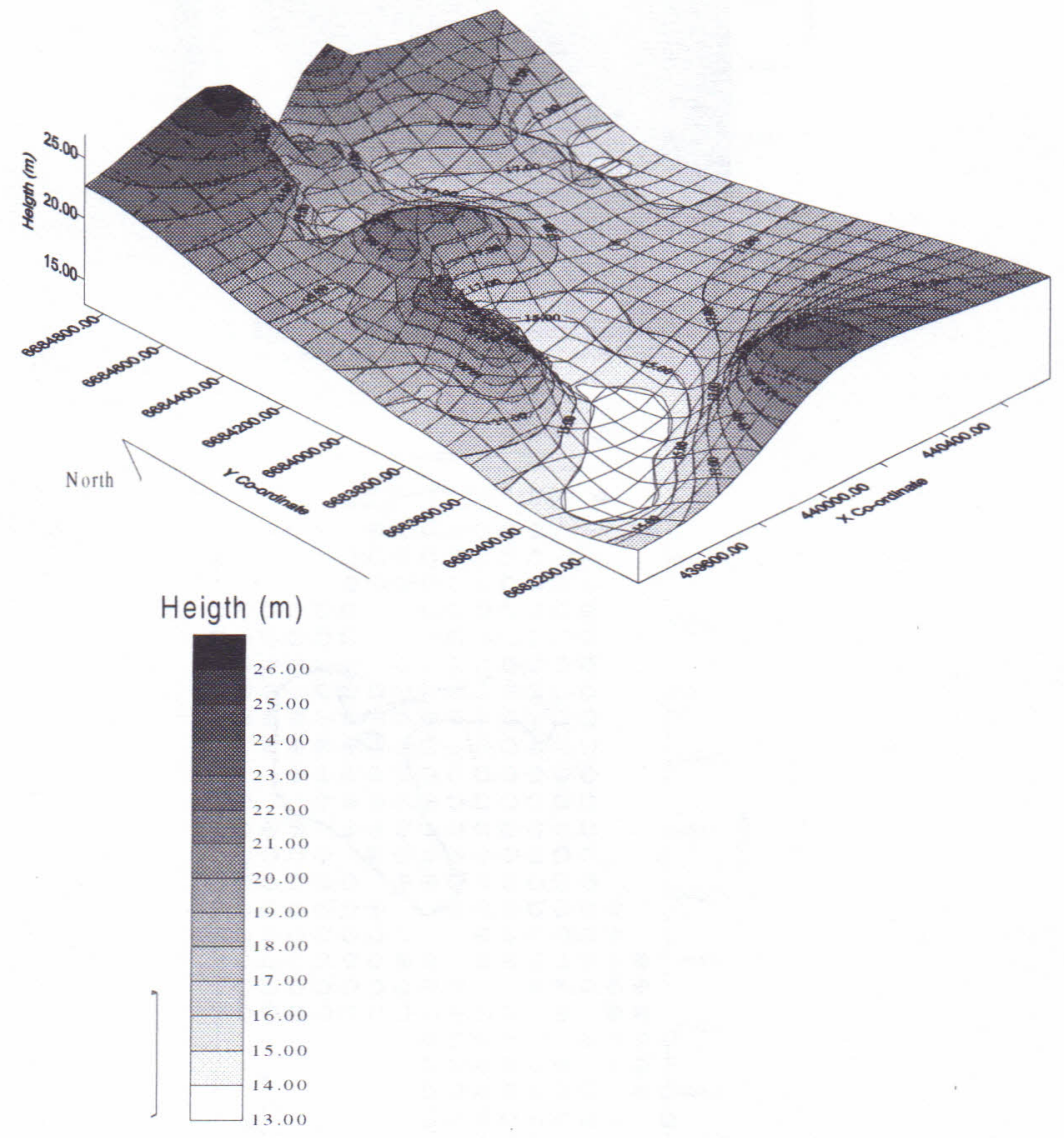

Figure 11. Representation of the topographical variations observed in the deposit $\mathrm{CH} 20$. 


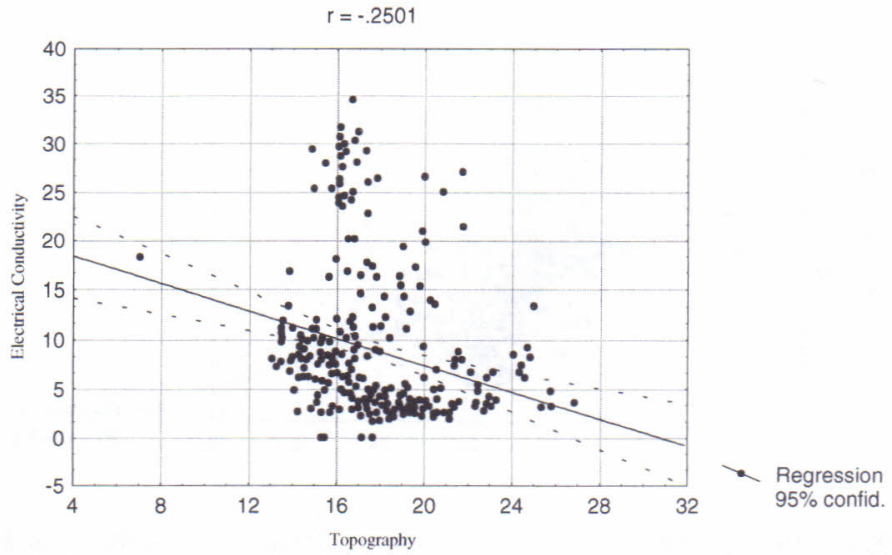

Figure 12: Correlation Topography $x$ electric Conductivity for the level $7.5 \mathrm{~m}$.

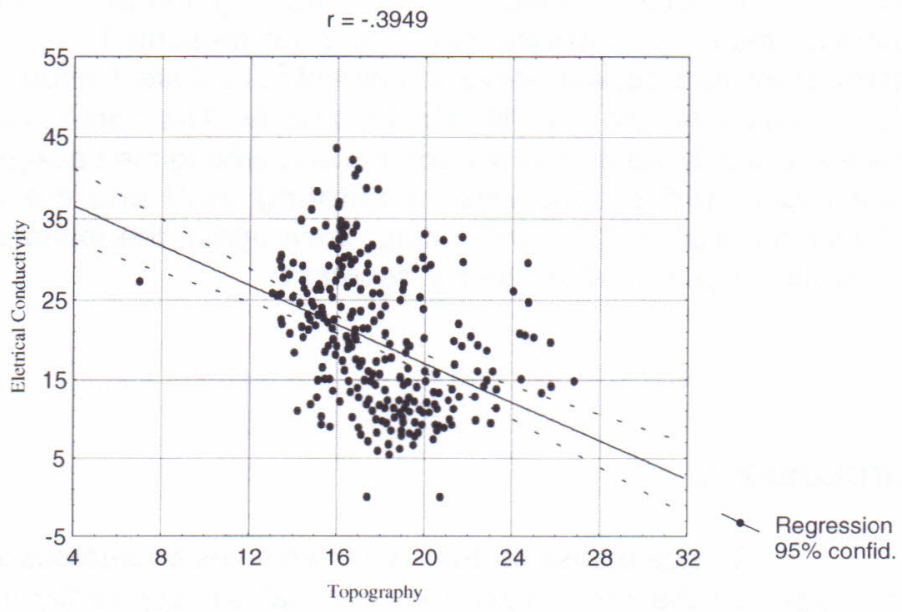

Figure 13: Correlation Topography $x$ electric Conductivity for the level $15 \mathrm{~m}$. 


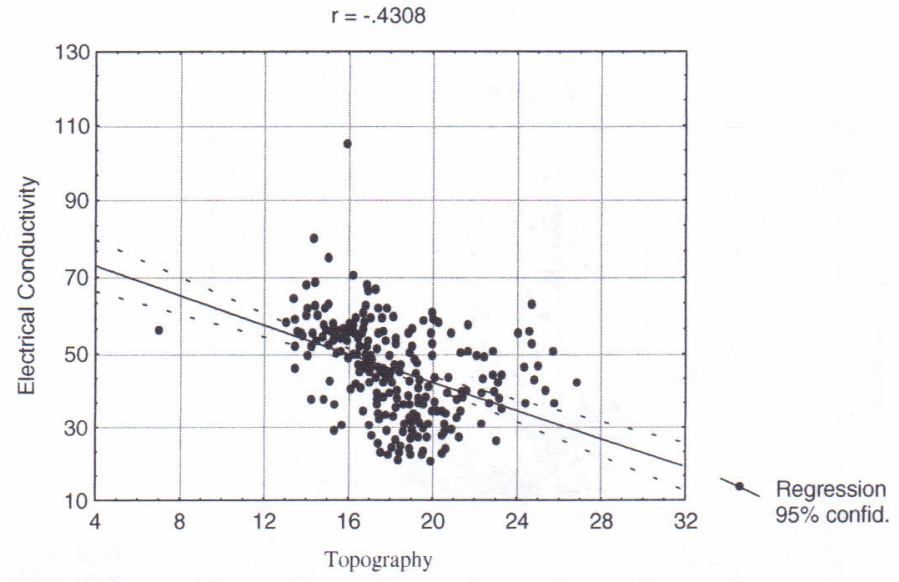

Figure 14: Correlation Topography $x$ electric Conductivity for the level $30 \mathrm{~m}$

\section{Complementary studies}

The Figure 15 presents the G.G.I. obtained for each groundwater monitoring well, from April/96 to April/97 (BINOTTO, 1997), located in the studied area. It can be seen that the greatest positive G.G.I. values correspond to the worst groundwater quality. In this way, the P2 groundwater monitoring well presented the highest contamination degree, with elevated contents of sulfate, Conductivity, TDS, ferrous iron, $\mathrm{Mn}, \mathrm{Cd}, \mathrm{Ni}, \mathrm{Cr}, \mathrm{Fe}$ and $\mathrm{Al}$. The contamination degree was easily verified by the comparison among the background of the region (P6 groundwater monitoring well) and the most contaminated well (P2), corroborating, once again, the influence of coal waste on groundwater quality decrease.

\section{CONCLUSIONS}

The geophysical study detected some anomalous areas that suggested the groundwater contamination, especially in the phreatic aquifer, originated from the inadequate disposal of coal waste and ashes. 


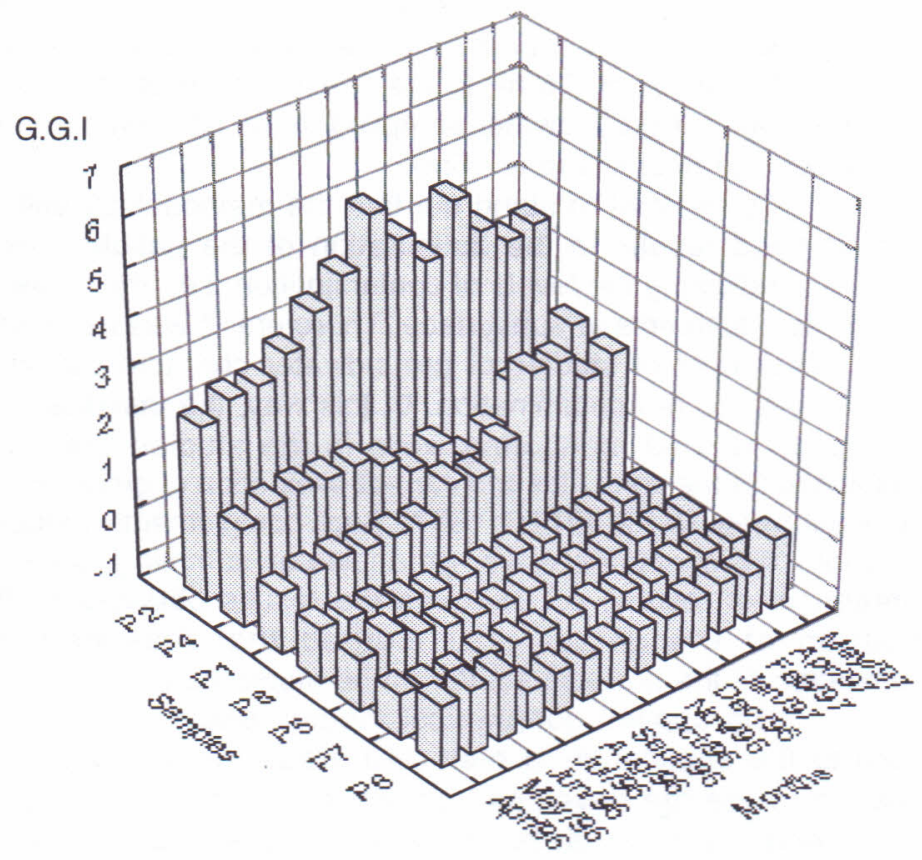

Figure 15: General Groundwaters Index for monitoring wells - Charqueadas City (P6, P1-P8).

In the external part of the deposit, the anomalous values that can be related to the deposit were just detected with the arrangement of smaller range, up to $7.5 \mathrm{~m}$ of depth, suggesting the formation of an incipient plume of contamination starting from the southern extremity of the deposit.

Inside the deposit, the obtained results suggest a strong contamination of the phreatic aquifer (level up to $7.5 \mathrm{~m}$ ), in almost all its extension. In the deepest levels, with better definition in the intermediary one (up to $15 \mathrm{~m}$ ), intense values concentrate on the NE part of the deposit, indicating a more intense infiltration of pollutants in this place due to presence of sandier, permeable layers, in the base of the deposit (BINOTTO, 1997, BINOTTO et al., 1999). 
The observed results suggest that, in areas of inadequate disposal of coal waste and ashes, the groundwater monitoring should be accomplished preferentially on the phreatic aquifer, until the depth of $7.5 \mathrm{~m}$. In the specific case of the $\mathrm{CH} 20$ deposit, the depth of groundwater sampling in the NE portion of the deposit should be deeper (up to $15 \mathrm{~m}$ ).

It's relevant to stand out that the methodology utilized presented good results in the delimitation of the polluted area, although not indicating the levels of contamination, i.e., the contents, of the polluting elements in subsurface. Therefore, it was necessary the accomplishment of studies of groundwater characterization to quantify its degree of contamination. In this way, the installation of appropriately located monitoring wells in the studied area was accomplished for the complete and correct evaluation of groundwater contamination degree (BINOTTO, 1997). Such complementary studies (installation of piezometric wells, groundwater sampling, analysis and treatment of results) corroborated the results obtained by the application of the geophysical method that indicated the contamination of the phreatic aquifer in the studied area.

The applied geophysical method seems to be more adapted to the application in restricted areas, without anthropic occupation, since the developed activities - electric conductivity measurements - could hardly be developed in wide areas, especially those urbanized, due to the interferents that can appear (constructions, fences, electric nets).

This method, as already commented, must be considered as orientative in character, being excellent in the definition of polluted areas and, mainly, of the blank point to be used. This is especially true in areas about which few geological and hydrological information are available, since it allows to define areas of low electric conductivity and, consequently, with low ionic concentration.

\section{Acknowledgments}

We are thankful to FINEP/PADCT-GTM and CNPq for the financial support for this work, to FEPAM Laboratory for the determination of metallic elements. 


\section{References}

ASSOCIAÇÃO BRASILEIRA DE NORMAS TÉCNICAS - ANBT. 1987.

Preservação e Técnicas de Amostragem de Efluentes Líquidos e Corpos Receptores: NBR 9898. Rio de Janeiro, 34P.

APHA. Standard Methods for the Examination of Water and Wastewater.

Greeberg, A. E.; Cleseeri, L.S.; Eaton, A.D (Eds.) 18 th edition. 1992.

BINOTTO R.B, TEIXEIRA E.C, SANCHEZ J.C.D; JABLONSKI A AND FORMOSO, M.L.L. Evaluation of groundwater quality from Baixo Jacuí coalfield, Rio Grande do Sul, State-Brazil. In: Proceedings of the Fourth International Symposium on Environmental Issues and Waste Management in Energy and Mineral Production,, Oct.1996, Cagliari, R.Ciccu (editor). 1996, 789-796.

BINOTTO R.B. Avaliação do grau de contaminação das águas subterrâneas em áreas de influência de resíduos do processamento do carvão. Porto Alegre, RS. Dissertação de Mestrado, PPGEMM UFRGS. 1997, 184p.

BINOTTO R.B, TEIXEIRA E.C, SÀNCHEZ J.C.D; NANNI, A .S.; FERNANDES, I.D. E MIGLIAVACCA, D.M.. Avaliação ambiental da região do Baixo Jacuí, RS, Brasil: localização, descrição e caracterização dos resíduos provenientes das atividades de processamento de carvão. Porto Alegre: FEPAM; CIENTEC, 1999, 40p.

COPELMI Mineração Ltda. Estudo Ambiental da Mina de Charqueadas. Porto Alegre. 1994, vol. I and II.

COSTA, A.F.U. \& FERLIN, C.A. Aplicação de métodos geofísicos para detecção de contaminação das águas subterrâneas. Revista ECOS, Porto Alegre. 1994, 2: 25-30.

ELLERT, N.; GREENHOUSE, J.; MONIER-WILLIANS, M. A Geofísica no Estudo da Poluição das Águas Subterrâneas. AMBIENTE Revista CETESB de Tecnologia, São Paulo. 1988, 2 (2):94-100.

ISO Water Quality - Sampling - Part 11: Guidance on the Sampling of Groundwaters: ISO/DP 5667-11 (document ISO/TC 147/SC 6 N 153). London. 1990, 12p.

MCNEILL, J.D. Eletromagnetic Terrain Conductivity Measurement at Low Industion Numbers. Geonics Limited TN-6. 1980,15p.

TEIXEIRA, E.C.; BINOTTO, R.B.; SANCHEZ, J.C.D.; JABLONSKI, A. FERNANDES, I.D.; SIMCH DA SILVA, J.C.; ROSSI, G. Mapping and characterization of coal processing waste disposal sites from Baixo Jacuí Region, RS, Brazil. In: Fourth Intern. Symp. on Environ. Issues and Waste Manag. Energy and Mineral Production, Ciccu, R. (ed.). Proc... S.Margherita di Pula, Cagliari, Italy. 1996, 231-238. 
RAQUEL BARROS BINOTTO ELBA CALESSO TEIXEIRA ANTÔNIO FLÁVIO UBERTI COSTA ARTHUR SCHIMIDT NANNI

Fundação Estadual de Proteção Ambiental - FEPAM

Rua Carlos Chagas 55/707

Porto Alegre - Rio Grande do Sul - Brazil E-mail : gerpro.pesquisa@ fepam.rs.gov.br 